\title{
CAN RELIANCE ON MULTIPLE PERFORMANCES MEASURES (RMPM) BOOST EMPLOYEE PRODUCTIVITY THROUGH EMPLOYEE LOYALTY?
}

\author{
Marthalia Putri $^{(a)}$ and Yuliansyah Yuliansyah ${ }^{\text {(b) }}$ \\ (a) Faculty of Economics and Business, University of Lampung, \\ e-mail: marthalia.putri@yahoo.co.id \\ (b) Lecturer in Accounting, Faculty of Economics and Business, University of Lampung, e- \\ mail: yuliansyah@feb.unila.ac.id
}

\begin{abstract}
The aim of the study is to investigate the extent to which reliance on multiple performances measures (RMPM) leverages employee productivity. Assuming that this relationship exists when an employee has a high level of loyalty, we survey nurses and doctors in several healthcare organisations in Bandar Lampung. Eighty-two returned surveys yielded usable datasets from 76 respondents. Analysing data with SPSS 19.0, we found that RMPM can leverage employee productivity through employee loyalty, but we found no direct effect of RMPM on employee productivity. This study enriches research on management accounting and on employee behaviour in the service sector, in particular in health care organizations.
\end{abstract}

Keywords: Reliance on multiple performances measures, loyalty, productivity, healthcare, Smart PLS

Abstrak: Tujuan dari penelitian ini adalah untuk meneliti sejauh mana reliance on multiple performances measures (RMPM) dapat meningkatkan produktifitas karyawan. Penulis berasumsi bahwa hubungan ini terjadi ketika seorang karyawan memiliki tingkat loyalitas kerja yang tinggi loyalitas. Dalam penelitian ini penulis melakukan studi survey terhadap perawat dan dokter di beberapa organisasi kesehatan (rumah sakit) di Bandar Lampung. Berdasarkan dari 82 survei yang kembali, 76 responden yang dapat diolah. Analisis data dengan menggunakan software SPSS 19,0, kami menemukan bahwa RMPM dapat memanfaatkan produktivitas karyawan melalui loyalitas karyawan, tapi kami tidak menemukan efek langsung dari RMPM pada produktivitas karyawan. Penelitian ini memberikan kontribusi atas pengayaan penelitian tentang akuntansi manajemen dan perilaku karyawan di sektor jasa, khususnya pada industri kesehatan.

Kata kunci: Reliance on multiple performances measures, loyalitas, produktivitas, Industri kesehatan, SmartPLS

\section{BACKGROUND}

Performance measurement is an integral part of management in achieving strategic priorities in a company (Abernethy et al. 2005; Chenhall 2005; Yuliansyah et al. 2017). Recently, researchers and practitioners use multiple-performance measuring systems to evaluate performance of both individuals and organizations (Grigoroudis et al. 2012; Ittner et al. 2003; Lau and Sholihin 2005; Sholihin et al. 2010; Hall 2008, 2011; Yuliansyah and Khan 2015; Grafton et al. 2010). Earlier performance measuring systems-based only on accounting have various weaknesses (Ittner and Larcker 2003; Kaplan and Norton 1996b, 1992). In contrast, one advantage of non-financial indicators is being able to 'capture key 
strategic performance dimensions that are not accurately reflected in short-term accounting measures' (Ittner et al. 2003, p. 717).

According to psychologists, RMPM is more fair to employees because they are evaluated from various aspects (de Waal 2010; de Waal and Counet 2009; de Waal et al. 2009). Fair evaluation increases the employee's work satisfaction (Lau \& Moser, 2008; Lau \& Sholihin, 2005; Sholihin \& Pike, 2009), and eventually increases loyalty. An employee's loyalty has a great effect on their productivity. Scholars suggest that in service companies, employee loyalty contributes considerable profit (Selvina and Yuliansyah 2016; Yuliansyah 2015). However, so far, we find no study with multi-indicators that loyalty can increase productivity. Most previous studies investigate the effect of measuring employee performance (see: Hall 2008, 2011) and organisational performance (Yuliansyah et al. 2017). Therefore, we investigate the effect of RMPM on the loyalty and productivity of employees.

As explained above, we use a loyalty construct as mediating factor of this study, because RMPM is fair to employees, particularly those working under a reward system. Employees want to give great service to the company and thereby increase their productivity and their rewards. Up to now, it was difficult to measure performance using non-financial methods, nor was it clear how a combination of financial and non-financial measurements should affect managerial performance (Lau and Sholihin 2005). The importance of RMPM is emphasized by Hartmann (2000) who study an evaluative supervising style which includes non-financial aspects. Hartmann (2000, p. 477), for instance, showed that:

"Based on RAPM (Reliance on Accounting Performance Measures), researchspecific hypotheses could be formulated about the usefulness of having multiple performance indicators [. . .and] about the effect of having non-financial or nonquantitative performance targets [. . .] So far, both theory development and empirical evidence [. . . ] are limited" (emphasis and parentheses added).

Manager performance measurement using RMPM is closely related to the study of effectiveness and evaluation of employee performance under supervision, because with RMPM, the performance measurement of top managers can increase.

Corporate targets include service, marketing and selling products, integrating management, and minimizing unprofitable cost. These targets eventually facilitate employee value that, in turn, creates self satisfaction in each individual and confirms their loyalty. Furthermore, loyalty increases commitment, and commitment to serious work increases productivity. In short, RMPM can increase loyalty and loyalty will eventually increase productivity.

We survey employees of a Healthcare company within a hospital. 'Health care is an important social issue, and stakeholders (for example, patients, governments, and insurers) have expectations of latency, throughput, and safety' (Bitter et al. 2013, p. 264). We selected respondents who have been working for more than five years, for the reason that their loyalty and idealism have been formed by then.

The paper is organized as follows: the next section, Section 2, reviews the literature and develops our hypotheses; Section 3 explains our research methodology; Section 4 contains results and discussion; and Section 5 is our conclusion. 


\section{REVIEW OF LITERATURE}

Reliance on Multiple Performance Measures (RMPM). Although recent studies find that financial accounting is primarily used for the company to develop theories and practice in management accounting, the role of accounting data as a performance control indicator has changed substantially (Hartmann 2000; Chenhall and Langfield-Smith 2007). Indeed, the use of accounting alone for performance measurement (APM) has some shortcomings (Ittner and Larcker 1998; Merchant 2006; Abernethy et al. 2013). Because of the drawbacks of using APM as a single indicator, numerous authors suggest that it should be complemented with non-financial or qualitative indicators (Abdel-Maksoud et al. 2010; Yuliansyah and Razimi 2015).

Complementing APMs with NFPMs could combine the advantages of financial measures as short-term indicator of progress with the long-term strategic non-financial aims of an organization, thus linking operational activities across functional boundaries (Chenhall 2005; Hall 2008; Chang 2009; Kaplan and Norton 1996b, 1996a). In addition, many authors suggest multi performance measures in reaction to the limitations of APM (Sholihin and Pike 2010; Sholihin et al. 2010; Widener 2006). Most studies attempt to capture broader information from diverse areas. Ittner, Larcker \& Randall (Ittner et al. 2003, p. 717) note that 'Supplementing traditional measures with a diverse mix of nonfinancial measures [...is] expected to capture key strategic performance dimensions that are not accurately reflected in short-term accounting measurements'.

Sholihin, Pike, and Mangena (2010) find that since RMPM is not directly aligned with employees benefits through appropriate reward systems, individuals throughout the organization have low motivation to execute organizational strategies. RMPM should focus behaviour on organizational objectives by encouraging employees to achieve their target, and by motivating and guiding them to accomplish positive tasks (van Veen-Dirks 2010; Yuliansyah and Khan 2015). Once the employees link their activities and actions to SOP and improved rewards, there is an improvement in organisational performance (Yuliansyah 2015).

In other words, a contribution is required from employees at lower levels in order to successfully achieve the organisation's strategic targets (Bedford et al. 2008; Kaplan and Norton 1992; Yuliansyah and Khan 2015). Similarly, 'an organization that is performing well is one that is successfully attaining its objectives; in other terms, it is effectively implementing an appropriate strategy' (Otley 1999, p. 364). We believe that to integrate RMPM with employees' work performance will improve the behaviour of the employees (de Waal 2010; de Waal and Counet 2009; de Waal et al. 2009). It will enhance employees' motivation to achieve their individual goals and to attain the overall organizational objectives (Hall, 2008; Kaplan \& Norton, 1992). According to Yuliansyah and Khan (2015)'s multiple performance measurement systems, organizational objectives will be achieved if the organization internally validates its employees' performance.

Hypothesis Development. Before elaborating the hypothesis on each interaction, we present here the research framework of the study:

RMPM and employee loyalty. Although previous studies of RMPM and loyalty are hard to find, we assume that there is a positive link between them. Hartmann \& Slapničar (2012) and (Burney and Matherly 2007) say that multiple peformance measurement has a 
positive effect in several ways, such as higher perceptions of justice and greater job satisfaction.

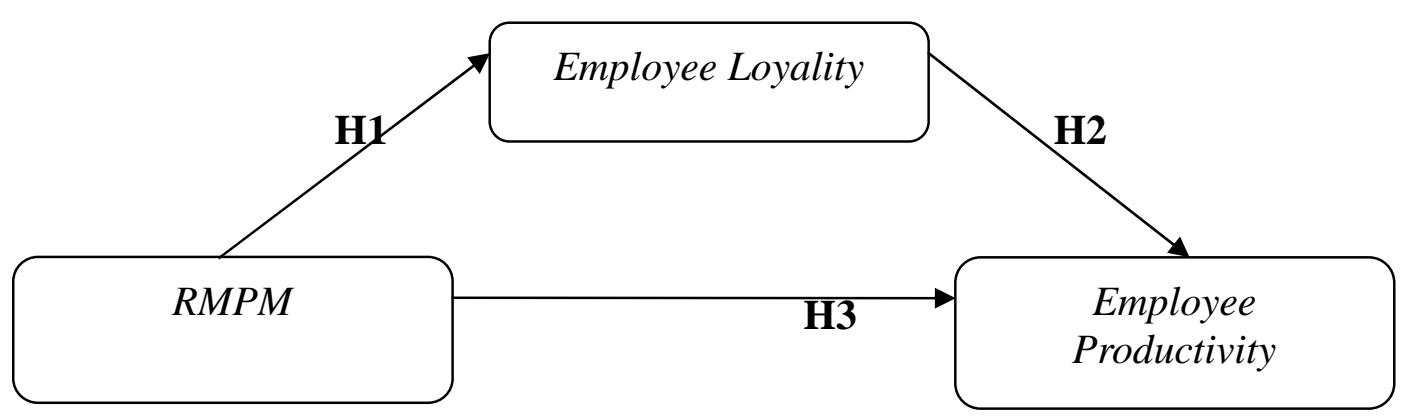

They are supported by Sholihin \& Pike (2009) and by Lau \& Moser (2008). Some scholars find a positive effect of RMPM on job satisfaction (Lau et al. 2008). That effect means lower employee turn over. Logically, if an employee works in a company with fair evaluation, they feel more satisfaction in their job. People resign if they feel sad and unhappy about their job. It follows that if an employee has higher job satifaction working in the company, it will increase their loyalty to the company (Matzler 2006). This leads us to believe that RMPM can increase employee loyalty through individual work satisfaction, and the hypothesis we propose is:

H1: There is a positive effect of RMPM on employee loyalty.

Employee Loyalty and Employee Productivity. As noted above, employee satisfaction is highly determined by a company's good appreciation of its employees (Heskett et al. 1994, 2008; Yuliansyah 2015). In the service sector, good feedback from an organisation is the critical determinant of individual performance (Roth and Van Der Velde 1991; Schlesinger and Heskett 1991b, 1991a). Prompt support increases job satisfaction and employee loyalty throughout an organization. Furthermore, loyalty can stimulate higher productivity (Heskett et al. 2008; Yuliansyah 2015). One way that job satisfaction can induce productivity is that employees are motivated to develop their skill and effort to do a better job (Heskett et al. 1994; Schlesinger and Heskett 1991b). Abu Al Rub \& Al-Zaru (2008) note the shortage of studies examining the relationship between loyalty and productivity. Their own research finds a positive link between loyalty and productivity in Jordanian hospital nurses (Taris and Schreurs 2009; AbuAlRub and AL-ZARU 2008). The hypothesis we propose is:

H2 : There is a positive effect of employee loyalty on employee productivity.

RMPM and Employee Productivity. We believe that there is a positive effect of RMPM on employee productivity. RMPM is based not only on accounting performance measures, but also on non-financial or qualitative indicators. A long time ago, Hopwood (1972) found that the use of accounting performance measurement systems can create disfunctional behaviour among employees. One limitation of accounting is that the measurements are not designed to help employees make decisions (Abernethy et al. 2013). Because of this shortcoming, APM should be complemented with non-financial or qualitative indicators (Yuliansyah and Razimi 2015; Hartmann 2000). 
Empirial studies show that there are positive effects of RMPM on individual productivity (Yuliansyah et al. 2016; Hall 2008, 2011; Sholihin et al. 2010). Thus, We propose the following:

$\mathbf{H 3}$ : There is a positive effect of RMPM on employee productivity

\section{RESEARCH METHOD}

Sample and Population of Study. Data used in this study are quantitative primary data, obtained from questionnaires filled in by healthcare employees in Lampung province. We choose healthcare as the object of study because employees in that field provide an excellent service and set a good example for society. In addition, in healthcare we find suitable respondents, that is, employees who have positions as middle managers to upper managers and who have a minimum of three years working experience.

Before we distribute the primary questionnaires, our preliminary surveys reduce the possibility of ambiguities in the questions and responses, thereby increasing the level of response. Other reasons to do a preminary survey are to 1) see the effectiveness of the questions, (2) ensure the questions are unambiguous, and (3) identify difficult questions in the interview guide (Holbrook et al. 2006; Urbach and Ahlemann 2010). The pilot study not only improves the quality of the questions, but also teaches us to manage and prioritize questions for different seniorities of respondent.

In this study we distribute 82 sets of questionnaires to individuals at 12 healthcare institutions. In order to enhance the response rate we visit the hospital to ensure that we meet the appropriate respondents in person. A week later, we come again in person to ask whether the completed questionare can be collected.

Table 1. below explains the percentage of distribution and return of study questionnaires:

Table 1. Percentage of Questionnaire Distribution and Return

\begin{tabular}{llll}
\hline No. & Description & Total & Percentage \\
\hline 1 & Distributed questionnaires & 82 & $100 \%$ \\
2 & Returned questionnaires & 76 & $93 \%$ \\
3 & Non-returned questionnaires & 6 & $7 \%$ \\
4 & Incomplete questionnaires & 0 & \\
5 & Usable questionaires & $\mathbf{7 6}$ & $\mathbf{9 3 \%}$ \\
\hline
\end{tabular}

Our sample, 76, appears in Table 2.

Table 2. General Information of Respondents

\begin{tabular}{llll}
\hline Information About & Information & Total & $\%$ \\
\hline \multirow{2}{*}{ Gender } & Male & 17 & 22 \\
\multirow{2}{*}{ TOTAL } & Female & 59 & 78 \\
\multirow{2}{*}{ Age } & & $\mathbf{7 6}$ & $\mathbf{1 0 0 \%}$ \\
& $<30$ years old & 45 & 59 \\
\hline
\end{tabular}




\begin{tabular}{llll}
\hline \multirow{2}{*}{ TOTAL } & $41-50$ & 2 & 3 \\
& $>51$ & 1 & 1 \\
Education & High School/Bachelor & 55 & 72 \\
& Undergraduate & 21 & 28 \\
SOTAL & S2/S3 & - & - \\
(Graduate/Postgraduate) & & \\
Position & Manager & $\mathbf{7 6}$ & $\mathbf{1 0 0 \%}$ \\
TOTAL & Non-Manager & 16 & 21 \\
Division of work & & 60 & 79 \\
TOTAL & Midwifery & $\mathbf{7 6}$ & $\mathbf{1 0 0 \%}$ \\
& Nursing & 32 & 42 \\
Type of Bank & Others & 13 & 17 \\
& 1 & 31 & 41 \\
& 2 & $\mathbf{7 6}$ & $\mathbf{1 0 0 \%}$ \\
TOTAL & 3 & - & - \\
\hline
\end{tabular}

Variable Measurement Instrument. Reliance on Multiple Performance Measures (RMPM). We measure the actual Reliance (the R in RMPM) with questions developed from the literature, and from those of Sholihin et al.(2010). We use ten multiple-choice questions. Each item on the questionnaire is measured by a Likert Scale of 1 to 5 where a " 1 " answer shows a not very important, and a " 5 " shows a very very important

Employee Loyalty. Employee loyalty is measured by five questions developed by Homborg and Stock (2000). Each item on the questionnaire is measured by a Likert Scale of 1 to 5 where a " 1 " answer shows a very low level, and a " 5 " shows a very high level.

Employee Productivity. Employee Productivity is defined as 'the outcome of individual [...] effort; it takes different forms under different circumstances and for different purposes' (Winata and Mia 2005). They used one question to ask about employee performance. In this study, we use a question: respondents are asked how much productivity they have in conducting work measured by a Likert Scale of 1 to 5 where a " 1 " answer shows a very low level, and a " 5 " shows a very high level.

\section{RESULT AND DISCUSSION}

Descriptive Statistics. Validity Test. Table 4 shows that the correlation coefficient of all statement items in each variable RMPM and EL $\geq 0.1876$, so all data are stated valid, and there is no statement item that must be eliminated or changed. EP statement items are not calculated because there is only one and it is descriptive. 
Table 3. Descriptive Statistics

Descriptive Statistics

\begin{tabular}{llllllll}
\hline & & & & & & & Std. \\
& $\mathrm{N}$ & Minimum & Maximum & Sum & Mean & Deviation \\
\cline { 2 - 7 } & Statistic & Statistic & Statistic & Statistic & Statistic & Std. Error & Statistic \\
\hline RMPM & 76 & 29 & 50 & 3379 & 44.46 & 0.654 & 5.698 \\
EL & 76 & 11 & 25 & 1595 & 20.99 & 0.406 & 3.538 \\
EP & 76 & 1 & 5 & 286 & 3.76 & 0.088 & 0.764 \\
Valid & $\mathrm{N}_{76}$ & & & & & & \\
(listwise) & & & & & & & \\
\hline
\end{tabular}

Table 4. Result of Validity Testing

\begin{tabular}{|c|c|c|c|}
\hline Statement Item & Correlation Coefficient & $\mathrm{r}_{\text {table }}$ & Conclusion \\
\hline \multicolumn{4}{|c|}{ Reliance on Multiple Performance Measure (RMPM) } \\
\hline 1 & 0.567 & 0.1876 & Valid \\
\hline 2 & 0.801 & 0.1876 & Valid \\
\hline 3 & 0.689 & 0.1876 & Valid \\
\hline 4 & 0.595 & 0.1876 & Valid \\
\hline 5 & 0.635 & 0.1876 & Valid \\
\hline 6 & 0.745 & 0.1876 & Valid \\
\hline 7 & 0.640 & 0.1876 & Valid \\
\hline 8 & 0.682 & 0.1876 & Valid \\
\hline 9 & 0.747 & 0.1876 & Valid \\
\hline 10 & 0.759 & 0.1876 & Valid \\
\hline \multicolumn{4}{|c|}{ Employee Loyalty (EL) } \\
\hline 1 & 0.638 & 0.1876 & Valid \\
\hline 2 & 0.675 & 0.1876 & Valid \\
\hline 3 & 0.594 & 0.1876 & Valid \\
\hline 4 & 0.576 & 0.1876 & Valid \\
\hline 5 & 0.592 & 0.1876 & Valid \\
\hline
\end{tabular}

Reliability Test. Table 5. shows that variables RMPM and EL are greater than 0.6, so the variables are reliable and they fulfill the requirement to conduct the next testing on those variables in this study.

Table 5. Result of Reliability Testing

\begin{tabular}{lll}
\hline Variable & Cronbach's Alpha & Conclusion \\
\hline RMPM & 0.897 & Very Reliable \\
EL & 0.819 & Very Reliable \\
\hline
\end{tabular}

The result of reliability testing above shows that variables RMPM and EL are greater than 0.6 , and the variables are reliable, so they fulfill the requirement to conduct the next testing on those variables in this study.

Multiple Linear Regression Test (R2). The statistical analysis used in this study, multiple linear regression, reveals the effect of an independent variable on a dependent variable. In this study, the effect of the independent variables, which are Employee Loyalty (EL) and Employee Productivity (EP), on the dependent variable, which is 
Reliance on Multiple Performance Measure (RMPM), can be seen and summarized in Table 6 below:

Table 6. Result of Multiple Linear Regression Analysis Coefficients ${ }^{\mathrm{a}}$

\begin{tabular}{|c|c|c|c|c|c|c|c|c|}
\hline \multirow{2}{*}{ Model } & \multicolumn{2}{|c|}{$\begin{array}{l}\text { Unstandardized } \\
\text { Coefficients }\end{array}$} & \multirow{2}{*}{$\begin{array}{l}\text { Standardized } \\
\text { Coefficients } \\
\text { Beta }\end{array}$} & & \multirow{2}{*}{ Sig. } & \multicolumn{3}{|c|}{ Correlations } \\
\hline & B & $\begin{array}{l}\text { Std. } \\
\text { Error }\end{array}$ & & & & $\begin{array}{l}\text { Zero- } \\
\text { order }\end{array}$ & Partial & Part \\
\hline$\overline{1}$ (Constant) & 28.489 & 3.995 & & 7.131 & 0.000 & & & \\
\hline EL & 0.711 & 0.179 & 0.441 & 3.962 & 0.000 & 0.455 & 0.421 & 0.413 \\
\hline EP & 0.281 & 0.831 & 0.038 & 0.338 & 0.736 & .194 & 0.040 & 0.035 \\
\hline
\end{tabular}

a. Dependent Variable: RMPM

Results above can be interpreted thus:

a. In the column of Standardized coefficient Beta in Table 6, the coefficient of variable EL is 0.711 , so we conclude that the coefficient of variable EL has a positive course. It means that if the measurement of RMPM is lower, then Employee Loyalty is better.

b. In the same column of Table 6 , the coefficient of variable EP is 0.281 , so we conclude that the coefficient of variable EP has a positive course. It means that if the measurement of RMPM is increasing, then Employee Production is better.

Table 7. Result of Multiple Linear Regression Analysis Coefficients ${ }^{\mathrm{a}}$

\begin{tabular}{|c|c|c|c|c|c|c|c|c|c|}
\hline & \multirow{2}{*}{ Model } & \multicolumn{2}{|c|}{$\begin{array}{l}\text { Unstandardized } \\
\text { Coefficients }\end{array}$} & \multirow{2}{*}{$\begin{array}{c}\text { Standardized } \\
\text { Coefficients } \\
\text { Beta }\end{array}$} & \multirow{2}{*}{$\mathrm{t}$} & \multirow{2}{*}{ Sig. } & \multicolumn{3}{|c|}{ Correlations } \\
\hline & & B & $\begin{array}{c}\text { Std. } \\
\text { Error }\end{array}$ & & & & $\begin{array}{l}\text { Zero- } \\
\text { order }\end{array}$ & Partial & Part \\
\hline 1 & (Constant) & 14.812 & 1.934 & & 7.660 & 0.000 & & & \\
\hline & EP & 1.641 & 0.504 & 0.354 & 3.257 & 0.002 & 0.354 & 0.354 & 0.354 \\
\hline
\end{tabular}

a. Dependent Variable: EL

c. In the column of standardized coefficient Beta in Table 7, the coefficient of variable EP is 1.642, so we conclude that the coefficient of variable EP has a positive course. It means that if Employee Loyalty is increasing, then Employee Productivity of an employee is getting better. Table 8 , the determination coefficient of $\mathrm{R}^{2}$ test, follows:

Table 8. Determination Coefficient Testing $\left(\mathrm{R}^{2} \mathrm{Test}\right)$

\begin{tabular}{lllll}
\hline \multicolumn{5}{c}{ Model Summary $^{\text {ab }}$} \\
\hline Model & $\mathrm{R}$ & R Square & $\begin{array}{l}\text { Adjusted R } \\
\text { Square }\end{array}$ & $\begin{array}{l}\text { Std. Error of the } \\
\text { Estimate }\end{array}$ \\
1 & 0.456 & 0.208 & 0.186 & 5.140 \\
\hline
\end{tabular}

a. Predictors: (Constant), EL,EP

b. Dependent Variable: RMPM

Based on the results in Table 8, we see that for a construct explaining the relation of RMPM toward EL and EP, the amount of adjusted R square value is 0.186 or $18.6 \%$. It means that the variability of independent variables in this study, which are employee loyalty and employee productivity, can explain their dependent variable, which is reliance 
on multiple performance measures (RMPM), by as much as $18.6 \%$. Meanwhile, the rest of the $81.4 \%$ is explained by other factors that are not tested in this study.

Table 9. Model Summary ${ }^{\mathrm{ab}}$

\begin{tabular}{ccccc}
\hline Model & $\mathrm{R}$ & $\mathrm{R}$ Square & $\begin{array}{c}\text { Adjusted } \mathrm{R} \\
\text { Square }\end{array}$ & $\begin{array}{c}\text { Std. Error of the } \\
\text { Estimate }\end{array}$ \\
\hline 1 & 0.354 & 0.125 & 0.114 & 3.331 \\
\hline
\end{tabular}

a. Predictors: (Constant), EP

b. Dependent Variable: EL

For a construct explaining the relation of EL toward EP, the amount of adjusted R square is 0.125 or $12.5 \%$. It means that variability of the independent variable in this study, which is employee loyalty, can explain its dependent variable, which is employee productivity, by as much as $12.5 \%$. Meanwhile, the rest of the $87.5 \%$ is explained by other factors that are not tested in this study.

Hypothesis Testing. RMPM and Employee Loyalty. The first hypothesis $\left(\mathrm{H}_{1}\right)$ stated that RMPM positively affects Employee Loyalty. The regression result shows that RMPM has a $\mathbf{t}$ calculated value of 3.962 at the significance level of 0.00 (see Table 4.6 above). The significance value of 0.000 is below the degree of confidence $(\alpha)$ of 0.01 , so the first hypothesis $\left(\mathrm{H}_{1}\right)$ is accepted.

Hypothesis 1 (H1) stating that RMPM positively affects Employee Loyalty is accepted. It means that RMPM increases employee loyalty. Hopwood (1972) shows that when an organization uses only accounting measures (APM), one factor causing the employee to have stress, among other effects, is suspicion about possible unemployment, and another factor is low loyalty. Hartman (2000) suggests that to be fair and to cover all aspects of performance measurement then RMPM is better than RAPM. In this study, we predict that employee loyalty increases because of RMPM. One characteristic of RMPM is rewards for employees who achieve.

Employee Loyalty and Employee Productivity. Our second hypothesis $\left(\mathrm{H}_{2}\right)$ is that employee loyalty positively affects employee productivity. The regression result shows a $\mathbf{t}$ calculated value of 3.257 at the significance level of 0.002 (see Table 4.7 above). The significance level of 0.002 is below the degree of confidence $(\alpha)$ of 0.01 , so the second hypothesis $\left(\mathrm{H}_{2}\right)$ is accepted.

Hypothesis 2 is accepted. This means that even though at this time we have not found any empirical evidence of relation between RMPM and employee productivity, we predict that it causes psychological aspects such as perceived comfort, justice, and safety. This conceptualisation is supported by Hall (2008), who uses a comprehensive system to measure performance. Hall measures cognitive aspect (role clarity) and motivational aspect (psychological empowerment) rather than directly addressing employee performance.

RMPM and Employee Productivity. The third hypothesis $\left(\mathrm{H}_{3}\right)$ is that competency positively affects quality of financial report responsibility. The regression result shows that competency variable has a $\mathbf{t}$ calculated value of 0.338 at the significance level of 0.736 (see Table 4.6). The significance level of 0.736 is above the degree of confidence $(\alpha)$ of 0.1 , so the third hypothesis $\left(\mathrm{H}_{3}\right)$ is rejected. 
This proves that when employees have loyalty to the organization, they will try to work hard in order to contribute more to the organization or in other words, their productivity increases. On the other hand, if employees do not have loyalty to the organization, they will work with little willingness and without paying attention to their productivity.

Path Test. A Path test is done when all data results show positive. In this study, a Path test is not done because from the data obtained, there are negative results.

\section{CONCLUSION AND SUGGESTION}

Statistically, we show that RMPM explains the positive relation between the construct and variables of employee loyalty and employee productivity. In other words, there is a direct relationship between RMPM and both employee loyalty and employee productivity. To show this was our objective. The study result also reveals a relation between employee loyalty and employee productivity, as expected. The direct relation (direct effect) of RMPM on employee productivity is smaller than its indirect relation (indirect effect) on employee loyalty. In the service sector, RMPM is appropriate because this sector requires frequent innovation, close evaluation, and active monitoring. RMPM in a hospital should increase productivity and especially the quality of service. Therefore, a training program related to costing will minimize mistakes in employee working procedure and will increase confidence in the regulations and SOP that are assigned.

This study has two limitations. The first is the sample size and the number of respondents. Useful datasets number only 76 because we have limited access to people who can accept and fill out the questionnaires. Secondly, the area of this study is only regional hospitals and private hospitals in Bandar Lampung City, so the data obtained may not apply to all of Indonesia.

Nevertheless, our conclusions are robust. We expect and suggest that future work with more respondents from a greater geographical area will again demonstrate that RMPM boosts employee productivity through its relationship with employee loyalty.

\section{REFERENCES}

Abdel-Maksoud, A., F. Cerbioni, F. Ricceri, and S. Velayutham. (2010) "Employee morale, non-financial performance measures, deployment of innovative managerial practices and shop-floor involvement in Italian manufacturing firms". The British Accounting Review 42 (1),36-55.

Abernethy, M. A., J. Bouwens, and L. Lent. (2013) "The role of performance measures in the intertemporal decisions of business unit managers". Contemporary accounting research 30 (3),925-961.

Abernethy, M. A., M. Horne, A. M. Lillis, M. A. Malina, and F. H. Selto. (2005) "A multi-method approach to building causal performance maps from expert knowledge". Management Accounting Research 16 (2),135-155.

AbuAlRub, R. F., and I. M. AL-ZARU. (2008) "Job stress, recognition, job performance and intention to stay at work among Jordanian hospital nurses". Journal of nursing management 16 (3):,227-236. 
Bedford, D. S., D. A. Brown, T. Malmi, and P.Sivabalan. (2008) "Balanced Scorecard design and performance impact: Some Australian evidence'. Journal of Applied Management Accounting Research 6 (2),17-36.

Bitter, J., E. van Veen-Berkx, H. G. Gooszen, and P. van Amelsvoort. (2013) "Multidisciplinary teamwork is an important issue to healthcare professionals'". Team Performance Management 19 (5/6),263-278.

Burney, L. L., and M. Matherly. (2007) "Examining Performance Measurement from an Integrated Perspective". Journal of Information Systems 21 (2),49-68.

Chang, H. H. (2009) "An empirical study of evaluating supply chain management integration using the balanced scorecard in Taiwan". Service Industries Journal 29 (2), 185-202.

Chenhall, R. H. (2005) "Integrative strategic performance measurement systems, strategic alignment of manufacturing, learning and strategic outcomes: an exploratory study". Accounting, Organizations and Society 30 (5),395-422.

Chenhall, R. H., and K. Langfield-Smith. (2007) "Multiple Perspectives of Performance Measures". European Management Journal 25 (4), 266-282.

de Waal, A. (2010) "Performance-driven behavior as the key to improved organizational performance". Measuring Business Excellence 14 (1),79-95.

de Waal, A., and H. Counet. (2009) "Lessons learned from performance management systems implementations". International Journal of Productivity and Performance Management 58:367-390.

de Waal, A., K. Kourtit, and P. Nijkamp. (2009) "The relationship between the level of completeness of a strategic performance management system and perceived advantages and disadvantages". International Journal of Operations \&\#38; Production Management 29:1242-1265.

Grafton, J., A. M. Lillis, and S. K. Widener. (2010) "The role of performance measurement and evaluation in building organizational capabilities and performance". Accounting, Organizations and Society 35 (7),689-706.

Grigoroudis, E., E. Orfanoudaki, and C. Zopounidis. (2012) "Strategic performance measurement in a healthcare organisation: A multiple criteria approach based on balanced scorecard". Omega 40 (1),104-119.

Hall, M. (2008) "The effect of comprehensive performance measurement systems on role clarity, psychological empowerment and managerial performance". Accounting, Organizations and Society 33 (2-3),141-163.

_ _ (2011) "Do comprehensive performance measurement systems help or hinder managers' mental model development?" Management Accounting Research 22 (2):68-83.

Hartmann, F., and S. Slapničar. (2012) "The perceived fairness of performance evaluation: The role of uncertainty". Management Accounting Research 23 (1),17-33.

Hartmann, F. G. H. (2000) "The appropriateness of RAPM: toward the further development of theory". Accounting, Organizations and Society 25 (4-5),451-482.

Heskett, J. L., T. O. Jones, G. W. Loveman, W. E. Sasser Jr, and L. A. Schlesinger. (1994) "Putting the Service-Profit Chain to Work". Harvard Business Review 72 (2),164170.

- (2008) Putting the service-profit chain to work. Harvard Business Review JulyAugust:118. 
Holbrook, A., C. Young Ik, and T. Johnson. (2006) "The impact of question and respondent characteristics on comprehension and mapping difficulties". Public Opinion Quarterly 70 (4), 565-595.

Homburg, C., and R. Stock. (2000) Der kundenorientierte Mitarbeiter. Gabler: Wiesbaden.

Hopwood, A. G. (1972) "An Empirical Study of the Role of Accounting data in Performance Evaluation". Journal of Accounting Research 10,156-182.

Ittner, C. D., and D. F. Larcker. (1998) "Are Nonfinancial Measures Leading Indicators of Financial Performance? An Analysis of Customer Satisfaction". Journal of Accounting Research 36 (3), 1-35.

_ . (2003) "Coming Up Short on Nonfinancial Performance Measurement". Harvard Business Review 81 (11), 88-95.

Ittner, C. D., D. F. Larcker, and T. Randall. (2003) "Performance implications of strategic performance measurement in financial services firms". Accounting, Organizations \& Society $28(7 / 8): 715$.

Kaplan, R. S., and D. P. Norton. (1992) "The Balanced Scorecard--Measures That Drive Performance". Harvard Business Review 70 (1), 71-79.

— . (1996a) "Linking the Balanced Scorecard to Strategy". California Management Review 39 (1),53-79.

_ (1996b) "Using the Balanced Scorecard as a Strategic Management System". Harvard Business Review 74 (1),75-85.

Lau, C. M., and A. Moser. (2008) "Behavioral Effects of Nonfinancial Performance Measures: The Role of Procedural Fairness". Behavioral Research in Accounting 20 (2),55-71.

Lau, C. M., and M. Sholihin. (2005) "Financial and nonfinancial performance measures: How do they affect job satisfaction?" The British Accounting Review 37 (4),389-413.

Lau, C. M., K. M. Wong, and I. R. C. Eggleton. (2008) "Fairness of performance evaluation procedures and job satisfaction: the role of outcome-based and nonoutcome-based effects". Accounting \& Business Research 38 (2),121-135.

Matzler, K. B. (2006) "The Relationship between Interpersonal Trust, Employee Satisfaction, and Employee Loyalty". Total Quality Management \& Business Excellence 17 (10),1261-1271.

Merchant, K. A. (2006) 'Measuring general managers' perfromances: Market, accounting and combination-of-measures systems". Accounting, Auditing \& Accountability Journal 19 (6),893-917.

Otley, D. (1999) "Performance management: a framework for management control systems research". Management Accounting Research 10 (4),363-382.

Roth, A. V., and M. Van Der Velde. (1991) "Operations as marketing: A competitive service strategy". Journal of Operations Management 10 (3),303-328.

Schlesinger, L. A., and J. L. Heskett. (1991a) Leonard A. Schlesinger and James L. Heskett Respond: "Customer Satisfaction Is Rooted in Employee Satisfaction". In Harvard Business Review: Harvard Business School Publication Corp., 148-149.

_ . (1991b) "The Service-Driven Service Company". Harvard Business Review 69 (5),71-81.

Selvina, M., and Y. Yuliansyah. (2016) "Relationships between Budgetary Participation and Organizational Commitment: Mediated by Reinforcement Contingency 
Evidence from the Service Sector Industries". INTERNATIONAL RESEARCH JOURNAL OF BUSINESS STUDIES 8 (2).

Sholihin, M., and R. Pike. (2009) "Fairness in performance evaluation and its behavioural consequences". Accounting \& Business Research 39 (4),397-413.

_ . (2010) "Organisational Commitment In The Police Service: Exploring The Effects of Performance Measures, Procedural Justice and Interpersonal Trust". Financial Accountability \& Management 26 (4),392-421.

Sholihin, M., R. Pike, and M. Mangena. (2010) "Reliance on multiple performance measures and manager performance". Journal of Applied Accounting Research 11 (1),24-42.

Taris, T. W., and P. J. Schreurs. (2009) "Well-being and organizational performance: An organizational-level test of the happy-productive worker hypothesis". Work \& Stress 23 (2), 120-136.

Urbach, N., and F. Ahlemann. (2010) "Structural equation modeling in information systems research using partial least squares". Journal of information Technology Theory and Application 11 (2),5-39.

van Veen-Dirks, P. (2010) "Different uses of performance measures: The evaluation versus reward of production managers". Accounting, Organizations and Society 35 (2), 141-164.

Widener, S. K. (2006) "Associations between strategic resource importance and performance measure use: The impact on firm performance". Management Accounting Research 17 (4):433-457.

Winata, L., and L. Mia. (2005) "Information technology and the performance effect of managers' participation in budgeting: evidence from the hotel industry". International Journal of Hospitality Management 24 (1),21-39.

Yuliansyah, Y. (2015) "Attributes Influencing Strategic Alignment in the Service Sector: An Indonesian Banking Sector Case Study". International Journal of Business, Economics and Management 2 (2), 34-48.

Yuliansyah, Y., B. Buih, and N. Mohamed. (2016) "How Managers Use PMS to Induce Behavioural Change in Enhancing Governance". International Journal of Economics and Management 10 (s2), 509-530.

Yuliansyah, Y., B. Gurd, and N. Mohamed. (2017) "The significant of business strategy in improving organizational performance". Humanomics 33 (1):56-74.

Yuliansyah, Y., and A. A. Khan. (2015) "Strategic Performance Measurement System: A Service Sector And Lower Level Employees Empirical Investigation". Corporate Ownership and Control 12 (3), 304-316.

Yuliansyah, Y., and M. S. A. Razimi. (2015) "Non-financial performance measures and managerial performance: the mediation role of innovation in an Indonesian stock exchange-listed organization". Problems and Perspectives in Management 13 (4), 135-145. 